\title{
Assess the Knowledge, Practice and Attitude Regarding Nosocomial Infections and their Preventive among Health Care Staff
}

\author{
Blessy Mohandass ${ }^{1}$, Amanpreet Kaur ${ }^{2}$ Timsy $^{2}$, Harmeet Kour ${ }^{3}$, \\ Navneet Kaur ${ }^{3}$, Pema Choden ${ }^{3}$, Aishwarya Thakur ${ }^{3}$ \\ ${ }^{1}$ Nursing Tutor, ${ }^{2}$ Assistant Professor, ${ }^{3}$ B.Sc. Nursing IVth Year Students, Chitkara School of Health Sciences, \\ Chitkara University, Punjab, India
}

\begin{abstract}
Nosocomial infections are diseases acquired within 48 hours or more of hospital admission or within 30 days of discharge. The objectives of the study were to assess the knowledge, attitude and practice regarding nosocomial infection and their prevention among health care workers. To determine the relationship between knowledge, attitude and practice regarding nosocomial infection and their prevention among health care workers. To find out association between the knowledge, attitude and practice regarding nosocomial infection and their prevention among health care workers. The research design selected for the study was descriptive research design and a total 100 health care staff were selected as study sample tool was used for data collection. Self-introduction was given and purpose of gathering the information and nature of study was explained before taking information through non probability convenient sampling technique. A self- structured questionnaire, consent was signed by participants. The result revealed that the most of the health care staff $76(76 \%)$ had excellent knowledge regarding nosocomial infection and their prevention less than half, $43(43 \%)$ had positive attitude regarding nosocomial infection and their prevention. On the contrary, 74(74\%) had excellent practice regarding nosocomial infection and their prevention. On applying the spearman correlation test, relationship between knowledge and attitude was found to be significant at $p<0.05$. Hence, researchers concluded that the present study was undertaken to identify the level of knowledge, attitude and practice regarding nosocomial infection and prevention among health care staff in selected hospitals of Punjab. The finding showed that majority of the participants had excellent knowledge and practice. There were gaps in relationship between knowledge and practice and attitude which is found to be not significant at $\mathrm{p}<0.05$.
\end{abstract}

Keywords: Knowledge, Infection, Practice, Nosocomial.

\section{Introduction}

Hospital acquired infections which are acquired or caught by a patient in a special location i.e. hospital and acquired after 48 hrs. On patient admission, 3 days of discharge and 30 days after surgery. ${ }^{1-2}$ Hospitalassociated infections also include occupational

\section{Corresponding Author:}

Amanpreet Kaur

Assistant Professor, Chitkara School of Health

Sciences, Chitkara University, Punjab, India infections due to occupational hazard in health care workers. $^{3-6}$ There is varioussort of transmissions of these microorganisms and virusacquired through direct contact between patient and doctor as well from patient to nurses and vice versa associated with nursing infected surface, through air such as droplets, aerosols etc. and also commonly through by common vehicles as food and water. ${ }^{7-9}$ Nosocomial infections go beyond their effects on morbidity and mortality in every country and have so many economic implications. Infection management should be a part of implementations for all health care workers, not only for their health purpose but also to decrease the prevalence of nosocomial 
infections and thus improve patient safety and risks of acquiring infections. ${ }^{10}$ Hand washing process leads to complete hand hygiene by healthcare staff has essential importance in the control of infections. ${ }^{11}$ Nosocomial infections increase the morbidity, mortality and duration of patients who stay at hospital prices. It is estimated that Nosocomial infections comprise more than 2 million patients per year. Negative outcomes of nosocomial infections differ by type of infection and their related costs. ${ }^{12}$ During the 1950s, programs for the surveillance, prevention and control of nosocomial infections were created. However, questions regarding the efficiency and cost-effectiveness of these programs still exist. ${ }^{13}$ That is why, this shows that knowledge regarding the effectiveness of nosocomial infection surveillance, prevention, and control is must emphasise on public health: screening, preventing and managing nosocomial infections.

\section{Materials and Method}

Research approach for the study was a quantitative research approach, as it allows the investigator to collect and cover data. In this analysis, the Descriptive research design was used, and a non-experimental research design was used to determine the knowledge, practice and attitude regarding nosocomial infections among health care workers in selected Hospitals of Punjab. A total 100 health care staff were selected as study sample tool was used for data collection. Self-introduction was given and purpose of gathering the information and nature of study was explained before taking information through non probability convenient sampling technique. A self- structured questionnaire, consent was signed by participants. In Inclusion Criteria all the health care worker i.e. Doctors, Nurses, Physiotherapist, OT Technician, Lab Technician, Radiologists who are in direct contact with the patient was selected for this study and in exclusion criteria health care staff that were not willing to participate was excluded. Using NonProbability Convenient sampling technique was selected to select a group of 100 healthcare staff who will be representative of the population being studied.

\section{Results}

The study revealed that present research was selected to assess the knowledge, practice and attitude of nosocomial infections and prevention for their health care staff in hospitals. The descriptive research design was selected. Non-Convenient sampling technique was selected for the study. The data was obtained from 100 health care workers who were analysed. The finding of the study for the showed that out of 100 subjects $76(76 \%)$ had excellent knowledge regarding nosocomial infection and their prevention and also 74 (74\%) had excellent practice regarding nosocomial infection and their prevention. So, this concludes that majority of the participants had excellent knowledge and practice and less than half had positive attitude. The second objective of the study findings revealed that relationship between the knowledge, practice and attitude of health care staff regarding nosocomial infection. In current study, on applying spearman's correlation test, relationship between knowledge and attitude was found to be significant at $p<0.05$. The relationship between knowledge and practice and attitude was found to be not significant at $p<0.05$. The findings of the study showed that there was a linear correlation between knowledge and attitude at $p<0.05$. Overall, there was no correlation between attitude and practice scores of individuals with regard to nosocomial infection prevention and control. The third objective findings revealed that the chi-square value showed that there was a significant association between knowledge and highest educational qualification. No significant association with the selected demographic variables was noted between attitude and practice. The results showed that nurses with a master's degree showed higher mean scores of knowledge than the other two groups. ${ }^{14}$ An important statistical difference in mean information scores was found at $\mathrm{p}<0.05$.

\section{Discussion}

Discussion deals with the results of the study. In the discussion, the investigator ties tighter all the loose ends of the study. The results and the discussion of the study are investigators opportunity to examine the logic of theoretical framework, the method and analysis. The present study was selected to assess the knowledge, practice and attitude regarding nosocomial infection and their prevention among health care staff in selected hospitals. Descriptive research method was selected and data was collected by self-reported paper and pencil. Data was collected from 100 health care staff that were analysed and interpreted. The relationship between knowledge and practice and relationship between attitude and practice was not significant at $\mathrm{p}<0.05$. Chi square value revealed that there was a significant association between knowledge and highest educational qualification. No significant association was seen between attitude and practice with their selected demographic variables. 
Table 1: Percentage and Frequency distribution of Knowledge, Attitude and Practice score of healthcare staff regarding nosocomial infections and their prevention $\mathrm{N}=100$

\begin{tabular}{|c|c|c|c|c|}
\hline Level of Knowledge Score & Percentage & Frequency & Mean & S.D. \\
\hline Excellent knowledge (9-12) & $76 \%$ & 76 & \multirow{3}{*}{9.64} & \multirow{3}{*}{1.77} \\
\hline Good knowledge (4-8) & $24 \%$ & 24 & & \\
\hline Inadequate knowledge $(<4)$ & $0 \%$ & 0 & & \\
\hline \multicolumn{5}{|c|}{ Maximum Score $=12$ Minimum Score $=0$} \\
\hline Level of Attitude Score & Percentage & Frequency & Mean & S.D. \\
\hline Positive Attitude (9-12) & $43 \%$ & 43 & \multirow{3}{*}{7.71} & \multirow{3}{*}{1.79} \\
\hline Neutral Attitude (4-8) & $51 \%$ & 51 & & \\
\hline Negative Attitude $(<4)$ & $6 \%$ & 6 & & \\
\hline \multicolumn{5}{|c|}{ Maximum Score $=12$ Minimum Score $=0$} \\
\hline Level of Practice Score & Percentage & Frequency & Mean & S.D. \\
\hline Excellent Practice (9-12) & $74 \%$ & 74 & \multirow{3}{*}{10.01} & \multirow{3}{*}{2.06} \\
\hline Good Practice (4-8) & $25 \%$ & 25 & & \\
\hline Poor Practice $(<4)$ & $1 \%$ & 1 & & \\
\hline \multicolumn{5}{|c|}{ Maximum Score $=12$ Minimum Score $=0$} \\
\hline
\end{tabular}

Table 2: Relationship between the knowledge, attitude and practice regarding nosocomial infections and their prevention among healthcare staff $\mathrm{N}=100$

\begin{tabular}{|c|c|c|c|c|c|}
\hline Relationship Between & Mean & S.D. & Correlation & $P$ value & Results \\
\hline Knowledge & 9.64 & 1.77 & \multirow{2}{*}{$0.418^{*}$} & \multirow{2}{*}{0.000} & \multirow{2}{*}{ Significant } \\
\hline Attitude & 7.71 & 1.79 & & & \\
\hline Knowledge & 9.64 & 1.77 & \multirow{2}{*}{0.139} & \multirow{2}{*}{0.167} & \multirow{2}{*}{ Not significant } \\
\hline Practice & 10.01 & 2.06 & & & \\
\hline Attitude & 7.71 & 1.79 & \multirow{2}{*}{0.025} & \multirow{2}{*}{0.802} & \multirow{2}{*}{ Not significant } \\
\hline Practice & 10.01 & 2.06 & & & \\
\hline
\end{tabular}

*Significant, ${ }^{\text {NS }}$ Not Significant

Table 3: Association between knowledge of healthcare staff regarding nosocomial infections and their prevention and selected socio demographic variables. $N=100$

\begin{tabular}{|c|c|c|c|c|c|c|c|}
\hline \multirow{2}{*}{ Variable Opts } & \multicolumn{3}{|c|}{ Level of Knowledge } & \multirow{2}{*}{$\begin{array}{l}\text { Chi } \\
\text { Test }\end{array}$} & \multirow{2}{*}{ P Value } & \multirow{2}{*}{ df } & \multirow{2}{*}{$\begin{array}{l}\text { Table } \\
\text { Value }\end{array}$} \\
\hline & Poor Knowledge & Good Knowledge & Excellent Knowledge & & & & \\
\hline \multicolumn{4}{|l|}{ Age } & \multirow{5}{*}{0.809} & \multirow{5}{*}{$0.847^{\mathrm{NS}}$} & \multirow{5}{*}{3} & \multirow{5}{*}{7.815} \\
\hline 21-25 years & 0 & 10 & 39 & & & & \\
\hline $26-30$ years & 0 & 8 & 23 & & & & \\
\hline $31-35$ years & 0 & 4 & 9 & & & & \\
\hline $36-40$ years & 0 & 2 & 5 & & & & \\
\hline \multicolumn{4}{|l|}{ Gender } & \multirow{3}{*}{1.606} & \multirow{3}{*}{$0.205^{\mathrm{NS}}$} & \multirow{3}{*}{1} & \multirow{3}{*}{3.841} \\
\hline Male & 0 & 12 & 49 & & & & \\
\hline Female & 0 & 12 & 27 & & & & \\
\hline
\end{tabular}




\begin{tabular}{|c|c|c|c|c|c|c|c|}
\hline \multirow{2}{*}{ Variable Opts } & \multicolumn{3}{|c|}{ Level of Knowledge } & \multirow{2}{*}{$\begin{array}{c}\text { Chi } \\
\text { Test }\end{array}$} & \multirow{2}{*}{ P Value } & \multirow{2}{*}{ df } & \multirow{2}{*}{$\begin{array}{l}\text { Table } \\
\text { Value }\end{array}$} \\
\hline & Poor Knowledge & Good Knowledge & Excellent Knowledge & & & & \\
\hline \multicolumn{4}{|c|}{ Highest Educational Qualification } & \multirow{5}{*}{9.904} & \multirow{5}{*}{$0.019^{*}$} & \multirow{5}{*}{3} & \multirow{5}{*}{7.815} \\
\hline Master & 0 & 15 & 25 & & & & \\
\hline Graduate & 0 & 4 & 39 & & & & \\
\hline Diploma & 0 & 3 & 5 & & & & \\
\hline Others & 0 & 2 & 7 & & & & \\
\hline \multicolumn{4}{|c|}{ Numbers of years in Healthcare practice } & \multirow{5}{*}{1.890} & \multirow{5}{*}{$0.595^{\mathrm{NS}}$} & \multirow{5}{*}{3} & \multirow{5}{*}{7.815} \\
\hline$\leq 1$ year & 0 & 4 & 22 & & & & \\
\hline $1-5$ years & 0 & 12 & 34 & & & & \\
\hline $6-10$ years & 0 & 5 & 10 & & & & \\
\hline $\begin{array}{l}\text { More than } 10 \\
\text { years }\end{array}$ & 0 & 3 & 10 & & & & \\
\hline \multicolumn{4}{|c|}{$\begin{array}{l}\text { Have You Ever Received Occupational Recently Any Training on Universal } \\
\text { Precautions? }\end{array}$} & \multirow{3}{*}{0.805} & \multirow{3}{*}{$0.370^{\mathrm{NS}}$} & \multirow{3}{*}{1} & \multirow{3}{*}{3.841} \\
\hline Yes & 0 & 19 & 53 & & & & \\
\hline No & 0 & 5 & 23 & & & & \\
\hline \multicolumn{4}{|c|}{$\begin{array}{l}\text { Maximum Score }=12 \\
\text { Minimum Score }=0\end{array}$} & \multicolumn{3}{|c|}{$\begin{array}{c}\text { *Significant } \\
\text { NS Not Significant }\end{array}$} & \\
\hline
\end{tabular}

Table 4: Association between Attitude of healthcare staff regarding nosocomial infections and their prevention and selected socio demographic variables. $N=100$

\begin{tabular}{|c|c|c|c|c|c|c|c|}
\hline \multirow[b]{2}{*}{ Variable } & \multicolumn{3}{|c|}{ Level of Attitude } & \multirow[b]{2}{*}{ Chi Test } & \multirow[b]{2}{*}{ P Value } & \multirow[b]{2}{*}{ df } & \multirow{2}{*}{$\begin{array}{l}\text { Table } \\
\text { Value }\end{array}$} \\
\hline & $\begin{array}{l}\text { Negative } \\
\text { Attitude }\end{array}$ & $\begin{array}{l}\text { Neutral } \\
\text { Attitude }\end{array}$ & $\begin{array}{l}\text { Positive } \\
\text { Attitude }\end{array}$ & & & & \\
\hline \multicolumn{4}{|l|}{ Age } & \multirow{5}{*}{6.880} & \multirow{5}{*}{$0.332^{\mathrm{NS}}$} & \multirow{5}{*}{6} & \multirow{5}{*}{12.592} \\
\hline $21-25$ years & 3 & 25 & 21 & & & & \\
\hline 26-30 years & 2 & 19 & 10 & & & & \\
\hline $31-35$ years & 1 & 6 & 6 & & & & \\
\hline $36-40$ years & 0 & 1 & 6 & & & & \\
\hline \multicolumn{4}{|l|}{ Gender } & \multirow{3}{*}{2.863} & \multirow{3}{*}{$0.239^{\mathrm{NS}}$} & \multirow{3}{*}{2} & \multirow{3}{*}{5.991} \\
\hline Male & 4 & 27 & 30 & & & & \\
\hline Female & 2 & 24 & 13 & & & & \\
\hline \multicolumn{4}{|c|}{ Highest Educational Qualification } & \multirow{5}{*}{9.851} & \multirow{5}{*}{$0.131^{\mathrm{NS}}$} & \multirow{5}{*}{6} & \multirow{5}{*}{12.592} \\
\hline Master & 5 & 21 & 14 & & & & \\
\hline Graduate & 0 & 22 & 21 & & & & \\
\hline Diploma & 1 & 2 & 5 & & & & \\
\hline Others & 0 & 6 & 3 & & & & \\
\hline \multicolumn{4}{|c|}{ Numbers of years in Healthcare practice } & \multirow{5}{*}{6.321} & \multirow{5}{*}{$0.388^{\mathrm{NS}}$} & \multirow{5}{*}{6} & \multirow{5}{*}{12.592} \\
\hline$\leq 1$ year & 1 & 16 & 9 & & & & \\
\hline $1-5$ years & 4 & 22 & 20 & & & & \\
\hline $6-10$ years & 1 & 9 & 5 & & & & \\
\hline More than 10 years & 0 & 4 & 9 & & & & \\
\hline
\end{tabular}




\begin{tabular}{|c|c|c|c|c|c|c|c|}
\hline \multirow[b]{2}{*}{ Variable } & \multicolumn{3}{|c|}{ Level of Attitude } & \multirow[b]{2}{*}{ Chi Test } & \multirow[b]{2}{*}{ P Value } & \multirow[b]{2}{*}{ df } & \multirow{2}{*}{$\begin{array}{l}\text { Table } \\
\text { Value }\end{array}$} \\
\hline & $\begin{array}{l}\text { Negative } \\
\text { Attitude }\end{array}$ & $\begin{array}{l}\text { Neutral } \\
\text { Attitude }\end{array}$ & $\begin{array}{l}\text { Positive } \\
\text { Attitude }\end{array}$ & & & & \\
\hline \multicolumn{4}{|c|}{$\begin{array}{l}\text { Have You Ever Received Occupational Recently any Training on } \\
\text { Universal Precautions? }\end{array}$} & \multirow{3}{*}{0.350} & \multirow{3}{*}{$0.839^{\mathrm{NS}}$} & \multirow{3}{*}{2} & \multirow{3}{*}{5.991} \\
\hline Yes & 4 & 38 & 30 & & & & \\
\hline No & 2 & 13 & 13 & & & & \\
\hline \multicolumn{4}{|c|}{$\begin{array}{l}\text { Maximum Score }=12 \\
\text { Minimum Score }=0\end{array}$} & \multicolumn{3}{|c|}{$\begin{array}{c}* \text { *Significant } \\
\text { NS Not Significant }\end{array}$} & \\
\hline
\end{tabular}

Table 5: Association between Practice of healthcare staff regarding nosocomial infections and their prevention and selected socio demographic variables. $N=100$

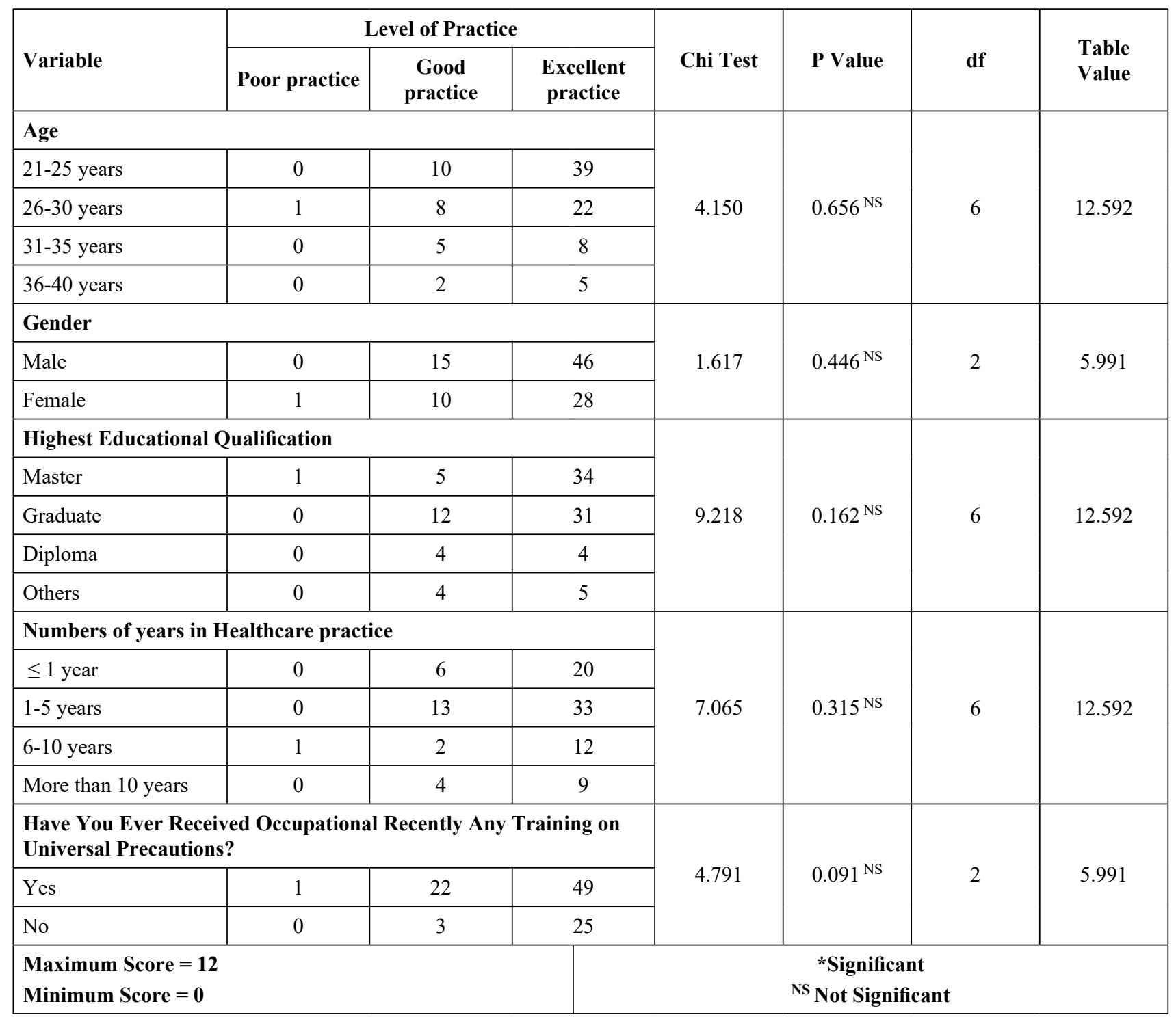

\section{Conclusion}

The study concluded that $76(76 \%)$ of the healthcare staff had excellent knowledge and prevention of nosocomial infection Less than half, 43(43\%) had positive attitude regarding nosocomial infection and their prevention. On the contrary, 74(74\%) had excellent practice regarding nosocomial infection and their prevention. On applying Spearman's Correlation test, 
relationship between Knowledge and Attitude was found to be significant at $p<0.05$. The relationship between Knowledge and Practice and the relationship between Attitude and Practice was found to be not significant at $\mathrm{p}<0.05$. The Chi-square value showed that there was a significant association between Knowledge and Highest Educational Qualification.

Acknowledgment: We would also like to thank Dr. Harmeet Kaur, Principal, Chitkara School of Health Sciences, Chitkara University Punjab India for her unending guidance during the period of our study.

Ethical Clearance: The ethical clearance was obtained from institutional research committee.

Source of Funding: Self

\section{Conflicts of Interest: None}

\section{References}

1. Alrubaiee G, Baharom A, Shahar H, Daud S, Basaleem H. Knowledge and practices of nurses regarding nosocomial infection control measures in private hospitals in Sana'a City, Yemen. Safety in Health. 2017;3(1).

2. Gadade M. A Study to Assess the Knowledge Regarding Nosocomial Infection among B.Sc. Nursing Students in Selected Nursing Institutions of Pune City. Journal of Medical Science And clinical Research. 2018;6(2).

3. Yogita M, Sangita R, Summaiya M. Impact of knowledge, attitudes \& practices among doctors, nurses \& ward aids for prevention \& control of tuberculosis infection in tuberculosis outpatient department and indoor patient department in tertiary care hospital. Journal of Patient Safety \& Infection Control. 2015;3(2):72-73.

4. Cherian V, Rajesh R. A Study to Assess The Knowledge and Practice among Nurse on Infection Control Measures in Pediatric Unit at Pondicherry Institute of Medical Science, Puducherry. International Journal of Advances in Nursing Management. 2018;6(3):215.

5. Fashafsheh I, Ayed A, Koni M, Hussein S, Thultheen I. Midwives and Nurses Compliance with Standard Precautions in Palestinian Hospitals. Open Journal of Nursing. 2016;06(04):294-302.
6. Gruda A, Sopjani I. The Knowledge, Attitudes and Practices of Nurses Toward Management of Hospital-acquired Infections in the University Clinical Center of Kosovo. Materia Socio Medica. 2017;29(2):84.

7. Knowledge and Practices of Nurses Regarding Spread of Nosocomial Infection In government Hospitals, Lahore. Journal of Liaquat University of Medical \& Health Sciences. 2017;16(03):149-153.

8. Kalantarzadeh M, Mohammadnejad E, Ehsani S, Tamizi Z. Knowledge and Practice of Nurses About the Control and Prevention of Nosocomial Infections in Emergency Departments. Archives of Clinical Infectious Diseases. 1901;9(4).

9. Lobo D, Sams L, Fernandez S. Correlation between health professionals knowledge, attitude and practice about infection control measures. Journal of Medical and Allied Sciences. 2019;9(1):26.

10. Mohapatra A. Assessment of Knowledge and Practice to Control Nosocomial Infection, Among the Staff Nurses, Hi-Tech Medical College and Hospital. Nursing \& Care Open Access Journal. 2017;2(1).

11. Najafi F, Jafari Motlagh Z, Dargahi A, Reshadat S, Moradi Nazar M. Knowledge, Attitude and Practice of Nurses Regarding Nosocomial Infections Control in Teaching Hospitals of Kermanshah University of Medical Sciences, Iran (2015). Archives of Hygiene Sciences. 2017;6(4):314-319.

12. Sodhi K, Shrivastava A, Arya M, Kumar M. Knowledge of infection control practices among intensive care nurses in a tertiary care hospital. Journal of Infection and Public Health. 2013;6(4):269-275.

13. Sarani H, Balouchi A, Masinaeinezhad N, Ebrahimitabas E. Knowledge, Attitude and Practice of Nurses about Standard Precautions for HospitalAcquired Infection in Teaching Hospitals Affiliated to Zabol University of Medical Sciences (2014). Global Journal of Health Science. 2015;8(3):193.

14. Shrestha G, Thapa B. Knowledge and Practice on Infection Prevention among Nurses of Bir Hospital, Kathmandu. Journal of Nepal Health Research Council. 2018;16(3):330-335. 